and triumph. God certainly has blessed and is blessing us now, for his Vicar on earth, the Sovereign Pontiff Leo XIII, has blessed you and blesses you now. You find the proof of that in the treasure of indulgences, partial and plenary, which he sent you last year. Be ye all enthusiastic propagandists for the project which I have announced; and with your fervent and constant prayers help the work which we undertake.

In the name of God, in the name of your wards, the lepers of Agua de Dios, in the name of religion and fatherland, I send you the most sincere thanks. And for all you have done, and all you may do in the future, all the glory will be solely for God and the salvation of souls.

Ad Majorem Dei Gloriam. I have said. PASTORAL.

We, Bernardo Herrera Restrepo, by the grace of God and of the Holy Apostolic See, Archbishop of Bogota, to the clergy and to the faithful of the Archdiocese:

All the good sons of Colombia who are animated with Christian charity toward their fellow men, are deeply concerned by the sad situation in which are placed so many of our brethren, who suffer this terrible disease of leprosy and its painful and inevitable consequences of isolation and perhaps of abandonment and utter want.

The church could not do less than take part in that general solicitude; and, therefore, if in other times and in similar circumstances, men especially called to help the poor diseased arose from among her ministers, now, too, by means of the sons of Don Bosco," she gives examples of love for the unfortunate lepers. They with the spirit of sacrifice which is above all praise, live among these unfortunates, nursing them as a father would, and offering them in life and death the consolations of religion.

Now the great work of the founding of the national lazaretto having been begun with the object of insuring to the lepers habitation and means of subsistence to make their lives less bitter and of opposing the spread of the contagion, the Salesian Fathers will announce and propagate this grand work in the whole republic. With that object, the Reverend Father Evasio Rabagliati prepares to journey about in the republic in order to persuade all to coöperate accord. ing to their means and to contribute with their alms and voluntary donations.

It is our duty to support this holy and charitable enterprise; and for that purpose, we appeal to the clergy and to the people of the republic, and especially of the city of the archdiocese entrusted to us, and we request everyone to give a hearing to the Christian sentiments of his heart, and to contribute as largely as he can to the founding of the national lazaretto, delivering into the hands of the Rev. Father D. Evasio Rabagliati the alms which he destines for that purpose.

Our Lord, God, will reward all those who help in this work of Christian love which we recommend; they will return an hundred-fold to the giver the goods which will be offered for the relief of those who cry like Job:" "Have pity upon me, have pity upon me, $O$ ye, my friends; for the hand of God hath touched me."

\footnotetext{
2 Brothers of the White Frock.

3 Job xix, 21 .
}

This pastoral shall be read twice in all the churches in the archdiocese. Given in Bogota, Aug. 4, 1895. BERNARDO,

Salustiano Gómez Riaño, Archbishop of Bogota. Canonical Secretary.

\section{CONGENITAL ABSENCE OF THE ESOPHAGUS.}

BY DANIEL LICHTY, M.D.

MEMBER OF THE AMERICAN MEDICAL ASSOCIATION ROCKFORD, ILL.

A writer in a late issue of the Journal, in an article on a subject remote from this, made the statement that "malformations of the internal organs of the fetus are still more rare than the various orthopedic lesions of the exterior body." In confirmation of this, a case of the above title came to my notice, whose rarity then impressed me, and it is here given to add to the peculiarities and mysteries of tissue growth in pre-natal life. If those who have the Index Medicus can find similar cases recorded in it, it would be interesting to know of them.

There was born in Rockford Hospital July 24, 1895, after a quite natural and easy labor, of a healthy Swedish mother aged 25, her third child, a male weighing six and three-fourths pounds, well formed and fully developed in all its external parts. After birth there was some of the obstructive mucous respiration often observed, which usually passes away after wiping the mouth, a drink of water, inverting the child and such like procedure. In this case, however, it persisted from day to day; it could nurse and seemingly swallow. There was nasal regurgitation, though the hard and soft palate and pharynx were perfectly normal; the gurgling respiration continued in spite of all efforts to relieve it, and on the eighth day the child died of inanition.

The privilege of a postmortem examination was obtained from the grieved but sensible parents. Exploration began by removing the sternum, dissecting through the thyroid isthmus, exposing and inspecting the larynx and trachea, which were each found normal except being filled with the ingested milk; a soft catheter was passed into the pharynx and esophagus which met obstruction that resisted further advance. Deeper dissection brought to light the esophagus ending in a distinct cul-de-sac, in which the tip of the catheter was engaged at the second dorsal vertebra. The lumen of the gullet was normal to this abrupt terminal. being about one centimeter in diameter, easily admitting a No. 12 catheter. Two centimeters below this and a little to the left, as would follow the normal course of the esophagus, began a fibrous impermeable cord one millimeter in diameter, very gradually increasing in size, in its passage through the diaphragm, until the natural dilatation of the stomach was attained, where its permeability was reëstablished, and the remainder of the alimentary tract was of normal form and function throughout. No other malformation was discovered.

Minnesota Coroner's Fees.-.-Where the coroner on the same day makes two separate examinations of two different dead bodies, or holds an inquest on one body and makes an examination of the other, the supreme court of Minnesota holds, in Kistler vs. Board of Commissioners of Hennepin County, decided June 24, 1896, that, under section 5554, General Statutes 1894, he is not entitled to a fee of five dollars for each examination and each inquest, or to anything more than five doliars per day " for the time actually spent." 